University of South Carolina

Scholar Commons

1971

\title{
Quantitative Analysis of Pinedale Landforms, Beartooth Mountains, Montana and Wyoming
}

William L. Graf

grafw@mailbox.sc.edu

Follow this and additional works at: https://scholarcommons.sc.edu/geog_facpub

Part of the Geography Commons

\section{Publication Info}

Arctic and Alpine Research, Volume 3, Issue 3, 1971, pages 253-261.

This Article is brought to you by the Geography, Department of at Scholar Commons. It has been accepted for inclusion in Faculty Publications by an authorized administrator of Scholar Commons. For more information, please contact digres@mailbox.sc.edu. 


\title{
QUANTITATIVE ANALYSIS OF PINEDALE LANDFORMS, BEARTOOTH MOUNTAINS, MONTANA AND WYOMING
}

\author{
William L. GRaF* \\ Department of Geography \\ University of Wisconsin \\ Madison, Wisconsin 53706
}

\begin{abstract}
The spatial distribution of terminal moraines in alpine valleys can be quantitatively described using distance/regression models. Surface parameters indicative of age may also be numerically analyzed. Evaluation of postglacial modification of valley sides between terminal moraines provides

segments. Analysis of the geomorphology of alpine features in the upper Rock Creek drainage in the southeastern Beartooth Mountains, Montana, shows that glaciers in this area deposited evidence of two Bull Lake, four Pinedale, and two Neoglacial advances.
\end{abstract} an additional indicator of relative age of valley

\section{INTRODUCTION}

The landforms resulting from glacial fluctuations in the Rocky Mountains of the western United States have been studied in numerous localities using widely diverse methods of analysis; Richmond (1965) reviews these studies. Although geologic factors such as till fabrics and soil profiles have been intensely studied, the distribution of moraines as landforms along the length of valleys has not been analyzed, and the spatial aspects of the characteristics of the valley sides between moraines have not been studied. This paper presents a new approach to identification and differentiation of glacial deposits in alpine valleys, with a distance/regression model that represents moraine distributions. A procedure is also given for analyzing the surface characteristics of valley sideslopes between the moraines.

*Present address: 1391 Lima Street, Apt. 101, Aurora, Colorado 80010.

\section{STUDY AREA}

The area selected for study is the upper Rock Creek drainage area of the Beartooth Mountains, Montana, where Rock Creek flows northeast from headwaters near the Montana-Wyoming border (Figure 1). The area includes the reaches of Rock Creek above Red Lodge, Montana, all of Lake Fork, and all of West Fork. The area is geologically and topographically typical of the range, which is an uplifted metamorphic block bounded by faults and upturned sedimentary rocks. Bedrock geology in the Rock Creek area is dominated by Precambrian schist and gneiss laced by occasional mafic dikes. Glacial troughs dissect the upland surface which is at an elevation of up to $3,350 \mathrm{~m}$ (11,000 feet). More than a dozen glaciers and ice bodies exist in the area; numerous clearly defined moraines indicate that former valley glaciers extended several kilometers from the cirques.

The evidence of glaciation and its record of

W. L. Graf / 253 


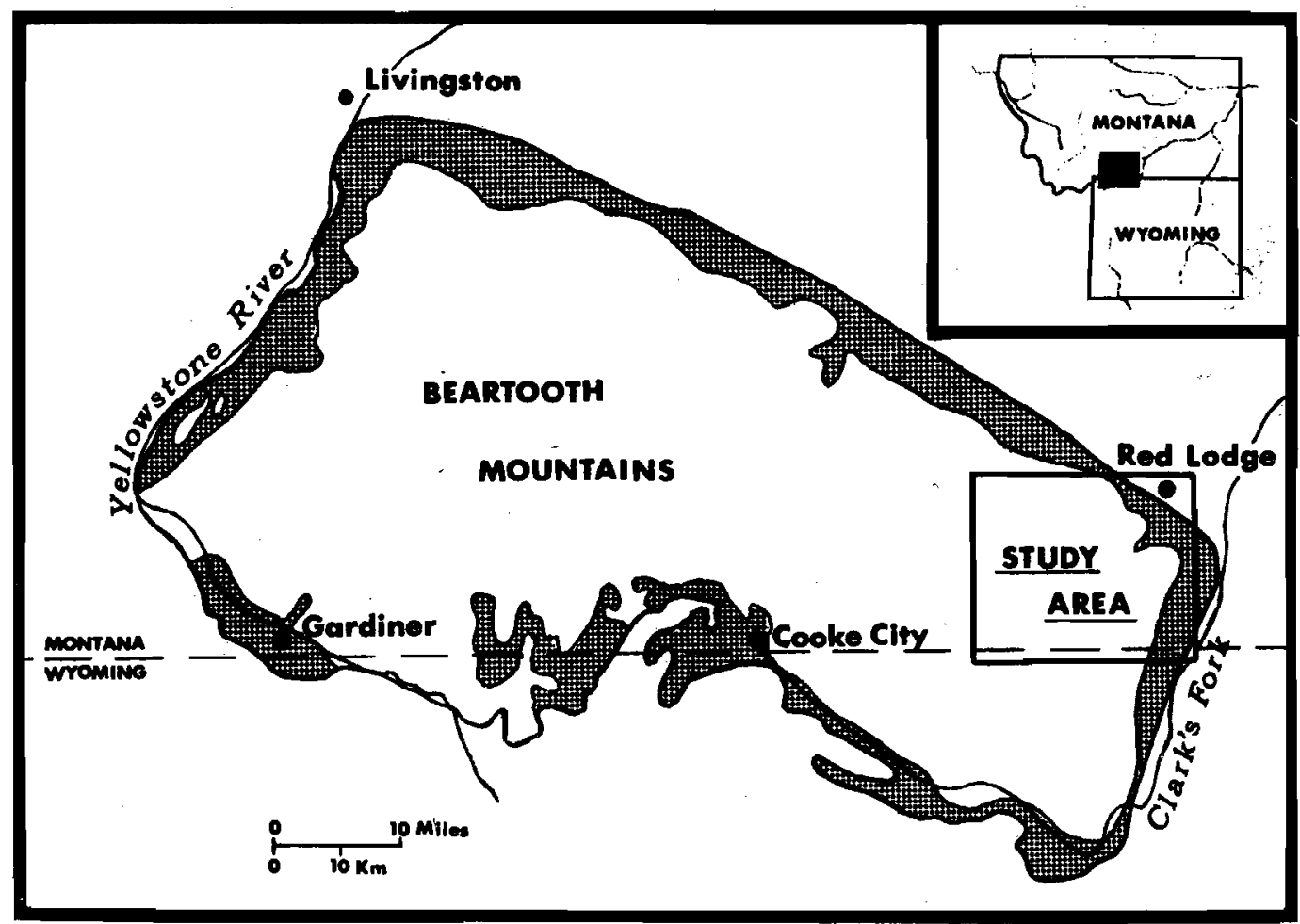

Figure 1. The Beartooth Mountains and the study area. Shaded area denotes extent of disturbed sedimentary rocks.

past glacial fluctuations has been little discussed in the literature. Bevan (1927) first commented on the glacial deposits of the Beartooth Mountains, but he did not investigate the Rock Creek area. The glacial chronology of the Wind River Range, south of the Beartooth Mountains, has been studied by several workers; to the west, the deposits of the Yellowstone Valley indicate a series of glacial fluctuations similar to those in the Wind River
Range (Holmes and Moss, 1955; Montagne, 1964). In view of these studies, the early, middle, and late Pleistocene ages assigned by Bevan (1946) to the glacial deposits of the Beartooth Mountains seem to be incorrect. A more exacting analysis of the glacial depositional geomorphology needed to produce a more detailed chronology of glacial advances is given here.

\section{METHODS OF INVESTIGATION}

Methods of analysis included procedures for (1) terminal moraine identification, (2) terminal moraine differentiation, (3) analysis of terminal moraine distribution, and (4) analysis of postglacial modification of valley segments between terminal moraines.

\section{TERminal MoRaIne IDENTIFICATION}

Glacial deposition features were identified on monochrome aerial photographs (scale $1: 15,840$ ) of the U.S. Forest Service. All positive anomalies greater than 20 feet $(6 \mathrm{~m})$ on the parabolic cross section of the glacial valley were considered, except for bedrock exposures and those features that obviously derived from slopes above (e.g. talus cones, landslide deposits). All other anomalies were considered possible glacial deposition features; changes in tone, texture, and slope outlined them in the aerial photographic interpretation procedure.

Once each feature was delineated, it was quantitatively evaluated in terms of size, shape, orientation with respect to the valley, distance from the 
valley center, and downvalley distance. Downvalley distance, measured from the valley headwall along the valley length to the farthest extent of the feature, was used as a location parameter. The other four measures were used to identify the feature. The shape of each depositional landform was expressed by a shape index $(S)$, which was the value of the length, measured along the semimajor axis of the planimetric outline, divided by the width, measured along the semiminor axis. The orientation with reference to the valley of each landform was given by the orientation index $(N)$, which was the angle formed by the intersection of the semimajor axis of the landform and the general directional trend of the valley. The cross valley distance $(C)$ of each landform was the distance from the thalweg (usually the center of the stream in the major valleys) to the outermost margin of the feature in meters. The size of each feature $(A)$ was expressed in terms of its planimetric area.

The shape index (dimensionless), orientation index (measured in degrees), and cross valley distance (measured in meters) were then combined to form the end moraine index $(M)$ :

$$
M=\frac{S N}{C}
$$

Dimensions were not used in the calculation of $M$. The formula for the end moraine index was designed so that end moraines had large $M$ values, lateral moraines had low values, and ice wastage and outwash features had intermediate values. Arbitrarily, features with $M$ values greater than 5 were considered to be probable moraines, and later field work indicated that this was a suitable dividing point. Several features in each valley had $M$ values greater than 5 . Size was used to determine which moraines were terminal and which were recessional. The end moraines of each valley had polymodal size distributions, and since terminal pasitions by their nature usually have larger landforms than recessional positions, those features in the mode of the largest size range were considered to be terminal moraines. Wherever possible, field examination checked this process of analysis. When $M$ values were plotted against downvalley distance, a definite sequence of values occurred at and near terminal positions. Downvalley, intermediate values of $M$ for ice wastage features occur, followed by low values of lateral moraines, high values of the terminal moraines, and intermediate values of outwash features.

Quantitative photo interpretation, verified by field checks, had several important advantages over more subjective identification of terminal positions. It reduced the amount of fieldwork required, since it permitted the sampling of the total population of features in the area. The quantification procedure indicated possible former terminal positions of glacial advances that left no terminal moraines (illustrated by incomplete sequences of $M$ values) and forced a rigorous, consistent examination of each landform. The procedure was relatively simple, removed at least some subjectivity from the study of glacial depositional landforms, and was designed to be duplicated in other areas for purposes of comparison.

\section{Terminal Moraine Differentiation}

Once identified by the procedure outlined above, a sample of the terminal moraines in the study area was examined in the field: Measurements of boulder frequency, boulder weathering, and slope angles provided quantitative data on the relative age relationships of the features; observations on the stream breaches and soil development provided additional data.

Boulder frequency on a given moraine was taken as the mean number of boulders $30 \mathrm{~cm}$ (1 foot) in diameter that occurred inside 15 randomly placed circles, each $3 \mathrm{~m}$ (10 feet) in diameter. For consistency, sampling was restricted to the crests of terminal moraines. The boulder weathering index was taken as the ratio of weathered to unweathered boulders on the crest of a given moraine in a randomly selected sample of 25 boulders of like composition. Weathered boulders were defined as those that had rounded edges and pits created by differential weathering; unweathered boulders had sharp outlines and lacked weathering pits. Slope angles were taken as maximum angles measured with a pocket transit on the moraine fronts, the sides away from ice sources, and were used for comparative purposes.

Additional observations were made on stream breaches and soil development, but these observations were not numerically analyzed because the age variable in their genesis could not be isolated. Stream breach width in moraines has been used in some previous studies (e.g., Nelson, 1954), but was not used in this study because it was not possible to determine how much of the stream breach was the result of increased discharge, of past climatic changes, or of the age of the feature. Many workers have measured soil development as an indicator of age, but such measurements were not numerically analyzed in this 
study because the moraines studied span several vertical vegetation zones. In order to use soil development as an age-controlled variable in the relative dating of materials, all the variables of soil genesis must be reasonably constant except time. Although useful for identifying Bull Lake and Pinedale deposits, soil development data are less successful in the differentiations of Pinedale stades (Madole, 1969). However, observations of thickness of soil development and weathering as exposed in natural cuts may be compared to data from other areas.

\section{Postglacial Modification of Valleys}

Many workers have noted that as glacially eroded features age, they are modified by postglacial processes. Sections of the glaciated valley downstream from a given moraine exhibit more modifications than segments upvalley from the moraine. The valleys may be divided into segments by the identified terminal moraines: the valley sides may then be classified into one of five categories of surface and material (Table 1).

In order to sample the side slopes of a given valley, profiles normal to the valley trend were investigated from the top of one side to the top of the other side of the valley. Initial determinations were made on aerial photographs but were also checked in the field in the summers of 1968,1969 , and 1970. The profiles were regularly space $0.3 \mathrm{~km}$ apart; they were eval-
TABle 1

Valley sideslope units

\begin{tabular}{lll}
\hline \multicolumn{1}{c}{ Unit } & Surface & Process \\
\hline Free face & Bare rock & Free fall \\
Scree slope & Scree & Creep, flow \\
Glacial deposition & Drift & Glacial \\
Glacial scour & Bare rock & Glacial \\
Alluvial slope & Alluvium & Fluvial \\
\hline
\end{tabular}

uated in terms of percentage of total profile length in each category. Mean percentages were calculated for each slope unit by valley segment.

Using this data the relative age of the valley segments can be demonstrated. Young segments have a high percentage of free face and a low percentage of scree slope and alluvial slope. Older slopes have a low percentage of free face and a high percentage of scree slope and alluvial slope. These differences, the result of varying lengths of time the profile has been subjected to postglacial modification, can be statistically tested for significance. A significant difference of means supports the relative dating of the terminal positions that constitute the segment boundaries and enforces their identification as true terminal positions.

\section{RESULTS}

\section{Moraine Distribution}

Application of these methods to the Rock Creek drainage area revealed 204 glacial depositional features and produced evidence of two Bull Lake, four Pinedale, and two Neoglacial advances (Figure 2, Table 2). The designations Bull Lake, Pinedale, and Neoglacial are used because of the similarity (in terms of morphology, distribution, and weathering) of the features in the Beartooth Mountains to the features at the type localities in the Wind River Range. The term Temple Lake is not used because of the questionable nature of the type locality. Field investigation in the Beartooth Range indicated patches of probable pre-Bull Lake till high on stream divides. These pre-Bull Lake deposits have been so completely weathered that they have no surface morphology to distinguish them from surrounding surficial deposits.

The two Bull Lake terminal positions in the valley of Rock Creek have large converging lateral moraines, but terminal moraines of this age have been erased by postglacial processes. The lateral moraines have multiple ridges, indicating several pulsations during deposition. Two major Bull Lake terminal positions occur in the valley of West Fork, in addition to two recessional positions. As in the valley of Rock Creek, the converging lateral moraines are multipleridged and do not join in a terminal moraine.

Pinedale features in Rock Creek, Lake Fork, and West Fork clearly indicate four advances, and in some cases multiple ridges indicate several pulsations during retreat of ice from the terminal positions. Large lateral and terminal moraines, ice wastage features, and outwash aprons are common Pinedale landforms. All valleys with Pinedale I moraines exhibit evidence of recessional moraines; other Pinedale positions do not have such universal recessional features (in this paper, the numerals following the terms are used to indicate separate glacial advances and are not moraine numbers). Numerous tributaries of the 


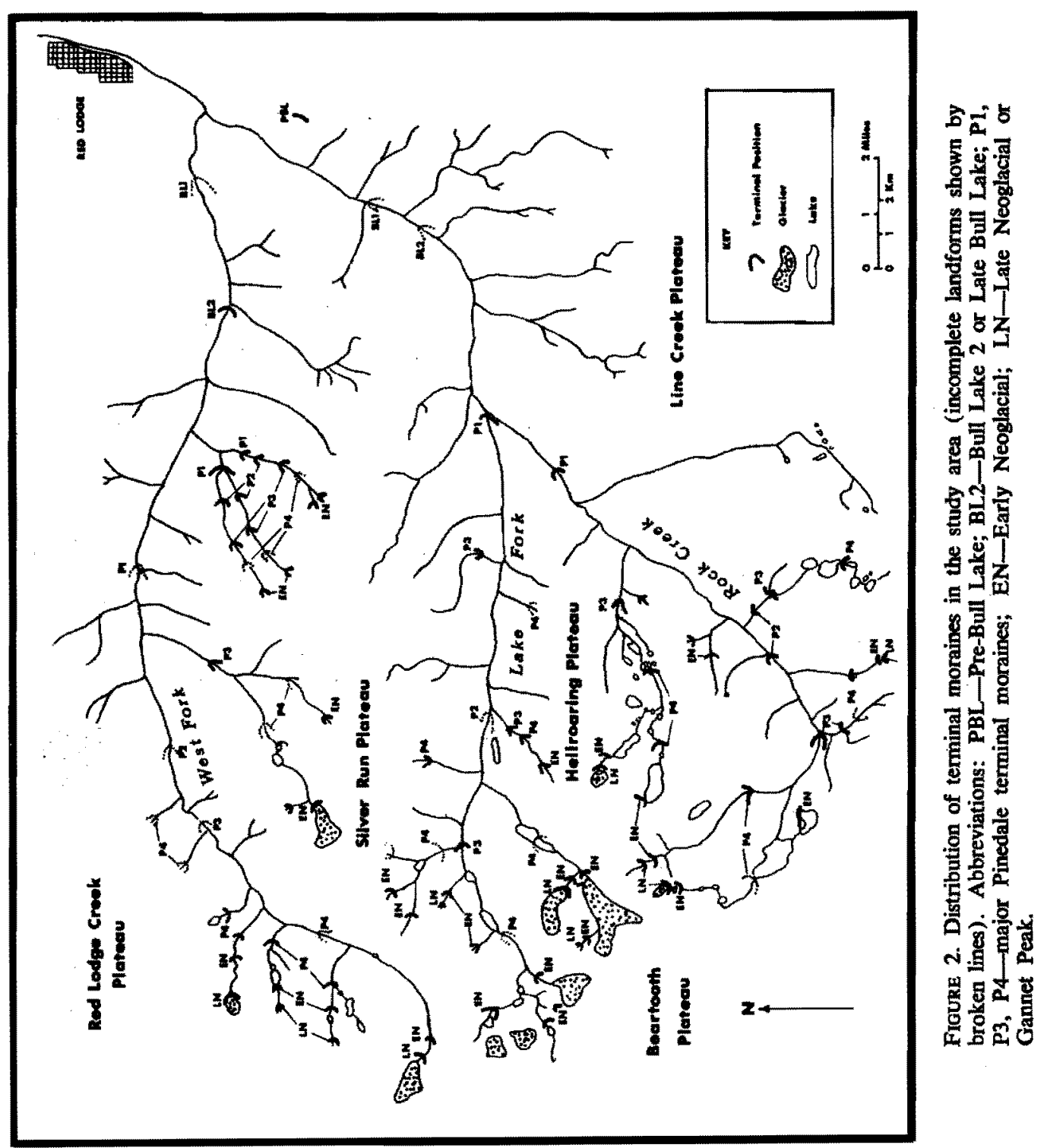


TABLE 2

Mean altitudes and downvalley distances

\begin{tabular}{lccc}
\hline \hline Terminal position & $N^{\mathrm{a}}$ & $\begin{array}{c}\text { Altitude } \\
(\mathrm{m})\end{array}$ & $\begin{array}{c}\text { Downvalley dist. } \\
(\mathrm{km})\end{array}$ \\
\hline Late Neoglacial & 13 & 3198 & 0.77 \\
Early Neoglacial & 24 & 3125 & 1.13 \\
Pinedale IV & 24 & 2897 & 2.67 \\
Pinedale III & 14 & 2623 & 4.86 \\
Pinedale II & 8 & 2442 & 6.45 \\
Pinedale I & 3 & 2252 & 12.33 \\
Bull Lake II & 2 & 1951 & 29.26 \\
Bull Lake I & 2 & 1865 & 31.99 \\
\hline
\end{tabular}

Number in study area.

main valleys contain evidence of some or all of the Pinedale advances; in many cases these valleys have only Pinedale III and/or Pinedale IV plus Neoglacial deposits because earlier tributary glaciers joined ice in the main valley.

Neoglacial deposits occur as a variety of landforms. Though in many places they are represented by two or three sharply defined moraines, they also occur as rock glaciers, transitional rock glacier-moraines, protalus lobes, and protalus ramparts. These features appear almost always as complete loops near the valley headwalls, and frequently they have several crests. In a few cases, existing glaciers rest against the most recent moraines.

\section{Moraine Surfaces}

Boulder frequency studies indicated that boulder frequency decreases with increasing age of moraine; boulders become progressively more common on the surfaces of younger moraines. Weathering indexes approach unity as older moraines are considered, indicating that greater percentages of sampled boulders show evidence of weathering. Slope measurements show that as moraines become older, slopes become more gentle.

Although very few absolute dates are available from alpine glacial deposits, tentative dates may be deternined from correlative deposits (Wright and Frey (1965) give a good review of chronologies). The numerical evaluations of the various surface features of the moraines can be correlated with age. Though dates in many cases are questionable, most are probably accurate to within two millenia. Tentative dates (in years BP) for the glacial deposits are Pinedale I, 23,000; Pinedale II, 14,000; Pinedale III, 11,500; Pinedale IV, 8,500; early Neoglacial, 2,800; and late Neoglacial, 400. The resulting regressions, given in Table 3, are least squares lines fitted to the data from 20 moraines with the above ages. In all cases, exponential functions provided the best fit. The relationship between age and the weathering index is not strong, probably because of inaccuracies in the method of designating boulders as weathered or unweathered. The remaining relationships between surface features and age are strong, with data from Pinedale IV moraines closely approximating the regression predicted values.

Other observations included stream breaches and soil development. Stream breaches through Bull Lake moraines are usually as wide as the valley floor, and in the valley of Rock Creek it appears that the main stream has cut $4 \mathrm{~m}$ into bedrock below the till. Flat-floored breaches in Pinedale I moraines are commonly up to $70 \mathrm{~m}$ wide; the main streams have eroded through the till in some cases, but none have cut into bedrock. In Pinedale II and Pinedale III moraines, breaches do not reach bedrock and are notches rather than flat-floored gaps. Pinedale IV moraines are only slightly breached and often impound small lákes. Neoglacial moraines are unbreached. Soil development is from 1 to $2 \mathrm{~m}$ in thickness on Bull Lake moraines and ranges from 30 to $50 \mathrm{~cm}$ on Pinedale I features; thickness decreases to 8 to $10 \mathrm{~cm}$ on Pinedale IV moraines. Neoglacial forms have slight soil development.

\section{Pinedale IV Moraines}

The sequence of glacial fluctuations interpreted from the evidence in the study area differs from previous studies in other areas in that there are four Pinedale advances. Pinedale I, II, and III seem to correlate with early, middle, and late Pinedale features in the Wind River Range; Pine- 
TABle 3

Surface feature/age regressions

\begin{tabular}{|c|c|c|}
\hline Regression ${ }^{\mathrm{a}}$ & $\begin{array}{l}\text { Correlation } \\
\text { coefficient }\end{array}$ & $\begin{array}{c}\text { Significance } \\
\text { level }\end{array}$ \\
\hline \multicolumn{3}{|l|}{ Boulder frequency } \\
\hline $\begin{array}{c}Y=\text { mean boulder frequency of sample } \\
X=\text { age }\left(\times 10^{3} \text { years }\right) \\
\qquad \log Y=1.7190-0.7209 X\end{array}$ & 0.9017 & 0.01 \\
\hline \multicolumn{3}{|l|}{ Weathering index } \\
\hline $\begin{array}{l}Y=\text { weathering index }(\times 100) \\
X=\text { age }\left(\times 10^{3} \text { years }\right) \\
\qquad \log Y=-3.3626+0.1849 X\end{array}$ & 0.3488 & 0.5 \\
\hline \multicolumn{3}{|l|}{ Front slope angle } \\
\hline $\begin{array}{l}Y=\text { slope }(\%) \\
X=\text { age }\left(X 10^{3} \text { years }\right) \\
\qquad \log Y=2.1185-1.0984 X\end{array}$ & 0.9360 & 0.01 \\
\hline
\end{tabular}

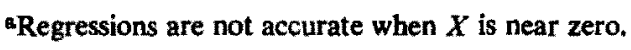

dale IV features occur upvalley from late Pinedale or Pinedale III moraines. Twenty-four valleys in the upper Rock Creek drainage have evidence of Pinedale IV deposits in the form of terminal or lateral moraines or fragments of moraines. These features have characteristics different from forms of other ages that are very consistent from one valley to another, and where an entire sequence of moraines cannot be observed, these characteristics may be at least partially diagnostic of age. Pinedale IV moraines are often series of sinuous ridges crossing valley floors of glacially polished bedrock, damming marshes or small lakes. Pinedale IV terminal positions often have a clearly definable recessional or readvance moraine just back of the terminal moraine; features of this age almost always have multiple crests. In this area they occur near the timberline, and lodgepole pine or krummholz may grow in the rocky till. Outwash aprons are rare in front of the moraines, and scattered patches of till and erratics occur upvalley between the last Pinedale and the first Neoglacial terminal positions. Multiple lateral moraines are frequently associated with Pinedale IV terminal positions, and in some cases they appear as linear till patches plastered on the valley walls.

The downvalley distances of the Pinedale IV terminal positions are remarkably consistent with respect to other moraines in the valleys. Regression models illustrate the distance relationships among early Neoglacial, Pinedale IV, and Pine- dale III moraines. The regression showing the downvalley distance of Pinedale IV $\left(D_{p . t}\right)$ in terms of the downvalley distance of Pinedale III $\left(D_{p 3}\right)$ is

$$
D_{p 4}=0.1831+0.5394 D_{p 3}
$$

The correlation coefficient ( $r$, Pearson's productmoment correlation) is +0.88 ; a Student's $t$ test shows the correlation to be significant at the 0.01 level of confidence. When the downvalley distance of the early Neoglacial moraine $\left(D_{e n}\right)$ is considered, the regression becomes

$D_{p 4}=0.0021+0.5139 D_{c n}+0.4862 D_{p 3}$

Here, the correlation coefficient is +0.9001 , also significant at the 0.01 level. These correlations do not necessarily imply causality, but they do provide a convenient description of the spatial relationships of the moraines; and the high correlation coefficients attest to the regularity of occurrence of Pinedale IV terminal positions in reference to nearby terminal positions of other ages. The coefficient of $D_{p 3}$ in each case is near 0.5 , indicating that Pinedale IV terminal positions usually occur about half way between valley headwalls (or nearby early Neoglacial moraines) and the Pinedale III terminal positions. The largest residuals from both regressions occur in the largest valleys, apparently because these large valleys had glaciers fed by ice from several cirques, with the glacial 
Table 4

Slope unit distribution (Rock Creek)

\begin{tabular}{|c|c|c|c|c|c|c|}
\hline Slope unit & Valley section & $N^{\mathbf{a}}$ & $\mathbf{S}^{2}$ & $\bar{X}_{1}^{b}$ & $t^{*}$ & $\begin{array}{c}\text { Significance } \\
\text { level }\end{array}$ \\
\hline Free face & $\begin{array}{l}\text { Neoglacial } \\
\text { Pinedale IV } \\
\text { Pinedale III } \\
\text { Pinedale II } \\
\text { Pinedale I } \\
\text { Bull Lake II }\end{array}$ & $\begin{array}{r}2 \\
12 \\
11 \\
10 \\
25 \\
10\end{array}$ & $\begin{array}{r}14.0 \\
12.5 \\
14.6 \\
11.1 \\
7.0 \\
3.4\end{array}$ & $\begin{array}{l}43.0 \\
24.8 \\
43.3 \\
43.3 \\
23.5 \\
3.8\end{array}$ & $\begin{array}{r}6.182 \\
10.224 \\
1.219 \\
16.040 \\
25.979\end{array}$ & $\begin{array}{l}0.01 \\
0.01 \\
0.25 \\
0.01 \\
0.01\end{array}$ \\
\hline Scree slope & $\begin{array}{l}\text { Neoglacial } \\
\text { Pinedale IV } \\
\text { Pinedale III } \\
\text { Pinedale II } \\
\text { Pinedale I } \\
\text { Bull Lake II }\end{array}$ & $\begin{array}{l}2 \\
12 \\
11 \\
10 \\
25 \\
10\end{array}$ & $\begin{array}{r}9.5 \\
13.1 \\
17.5 \\
13.3 \\
10.9 \\
9.1\end{array}$ & $\begin{array}{l}23.5 \\
36.4 \\
37.5 \\
46.1 \\
58.2 \\
76.3\end{array}$ & $\begin{array}{r}4.408 \\
0.642 \\
4.798 \\
8.762 \\
14.942\end{array}$ & $\begin{array}{l}0.01 \\
0.75 \\
0.01 \\
0.01 \\
0.01\end{array}$ \\
\hline Alluvial slope & $\begin{array}{l}\text { Neoglacial } \\
\text { Pinedale IV } \\
\text { Pinedale III } \\
\text { Pinedale II } \\
\text { Pinedale I } \\
\text { Bull Lake II }\end{array}$ & $\begin{array}{r}2 \\
12 \\
11 \\
10 \\
25 \\
10\end{array}$ & $\begin{array}{l}0.0 \\
0.0 \\
2.5 \\
5.8 \\
7.7 \\
6.4\end{array}$ & $\begin{array}{r}0.0 \\
0.0 \\
2.6 \\
6.5 \\
13.3 \\
18.9\end{array}$ & $\begin{array}{c}\text { no } \\
4.800 \\
4.270 \\
6.966 \\
5.614\end{array}$ & $\begin{array}{l}\text { erence } \\
0.01 \\
0.01 \\
0.01 \\
0.01\end{array}$ \\
\hline
\end{tabular}

Number in study area.

bMean percentage of total cross section profile.

$q_{l}$ values calculated for difference of means between each entry and the value below it.

system in each cirque responding to climatic changes in a slightly different manner. The relationships are strongest in valleys where ice from a single cirque fed the valley glacier.

\section{Postglacial Modification of Valleys}

The mean percentages of free face, scree slope, and alluvial slope are given in Table 4. Bull Lake
II, Pinedale I, and Pinedale II valley segments differ significantly among themselves in all categories, and the later moraines differ significantly in at least one category. Alluvial slopes increase downvalley from the Pinedale IV moraines. These results indicate that the moraines separating the valley segments are significant dividing lines for geomorphology as well as time.

\section{CONCLUSIONS}

The analysis presented in this paper stresses the spatial distribution of landforms, rather than the strictly geologic investigations of many previous workers. While the study of till bodies is necessary to the understanding of glacial landforms in the alpine environment, the surface of those till bodies provides an equal if not greater amount of information on past glacial fluctuations. Standard procedures for the analysis of till fabrics have been used by many workers, but there seems to be no standard method of analyzing surface forms or means of representation of their distribution. The concepts presented in this paper are intended to stimulate similar attempts in other areas and repre- sent only the first approximation to a standard procedure which might reduce subjectivity in the study of moraine sequences.

Application of the quantitative analysis to a portion of the southeastern Beartooth Mountains revealed series of moraines very similar to series in the Wind River Range of Wyoming, except that the Beartooth area had considerable evidence of four Pinedale advances rather than the three reported in the Wind River area. Boulder frequency, weathering, and slope angles indicate that Pinedale IV moraines are not recessionals of Pinedale III glaciers; yet their small size and fragmented appearance suggest that they are not the 
product of a major glacial advance. Pinedale IV deposits, then, apparently are the result of a readvance of Pinedale:III ice; evidence of similar age deposits from other regions, such as deposits of Lake Bonneville, suggests that this is the case (Morrison, 1965). Kiver (1968) has reported spatial relationships for a fourth Pinedale moraine in the Medicine Bow Mountains of Wyoming which are very similar to the relationships expressed in equations (2) and (3) in this report. The extreme regularity of occurrence of these moraines in the upper Rock Creek drainage area suggests that they are the result of a significant glacial event of at least regional magnitude.

\section{ACKNOWLEDGMENTS}

I am indebted to Dr. Donald R. Currey, Department of Geography, University of Utah, for his helpful suggestions during the research on the Pinedale IV problem. Dr. John Montagne, Department of Geology, Montana State University, provided valuable learning experiences in the field

\section{REFERENCES}

Bevan, A. C.

1927 : Glaciation of the Beartooth Mountains, Montana. Geol. Soc. Amer, Bull., 38: 142-143.

1946 : Three stages of Pleistocene glaciation in the Beartooth Mountains, Montana. Geol. Soc. Amer. Bull., 57: 1178.

Holmes, G. W. and Moss, J. H.

1955 : Pleistocene geology of the southwestern Wind River Mountains, Wyoming. Geol. Soc. Amer. Bull., 66: 629-654.

Kiver, E. P.

1968 : Geomorphology and glacial geology of the southern Medicine Bow Mountains, Colorado and Wyoming. Unpublished Ph.D. thesis, Univ. of Wyoming. 129 Madole, R. F.

1969 : Pinedale and Bull Lake glaciation in Upper St. Vrain Drainage Basin, Boulder County, Colorado. Arctic and Alpine Res., 1: 270-287.

Montagne, J.

1964 : Pre-Wisconsin glaciation and its effect in Yellowstone Valley, Montana, Geol. Soc. Amer. Bull., Spec. Pap. 76, 284. 285. despite his busy schedule. Dr. George H. Dury, Departments of Geography and of Geology and Geophysics, University of Wisconsin, provided helpful comments on this manuscript. A special note of gratitude is due to my wife, Lori, for valuable moral support.

Morrison, R. B.

1965 : Quaternary geology of the Great Basin. In Wright, H. E., Jr. and Frey, D. G. (eds.), The Quaternary of the United States. Princeton Univ. Press, Princeton, 265-285.

Nelson, R. L.

1954 : Glacial geology of the Frying Pan River Drainage, Colorado. J. Geol., 62: 325-343

Richmond, G. $M$.

1965: Glaciation of the Rocky Mountains, In Wright, H. E., Jr., and Frey, D. G. (eds.), The Quaternary of the United States. Princeton Univ. Press, Princeton, 217-230.

Ms submitted October 1970 Revised Ms submitted March 1971 